\title{
Toxicity of Bioactive Compound from Endophytic Fungi Isolated from Red Ginger (Zingiber officinale var. rubrum) Utilizing Brine Shrimp Lethality Assay
}

\author{
ANGGA PRASETYO ${ }^{1}$, BOY RAHARDJO SIDHARTA ${ }^{2}$, YUSTINA SRI HARTINI ${ }^{3}$, \\ EXSYUPRANSIA MURSYANTI ${ }^{1}$ \\ ${ }^{1}$ Faculty of Biotechnology, Universitas Atma Jaya Yogyakarta \\ Jl. Babarsari 44, Yogyakarta, Indonesia. 55281 \\ Email: saprasetyo5@gmail.com; mursyantiexsyupransia@gmail.com \\ ${ }^{2}$ Bioindustry Laboratory, Faculty of Biotechnology, Universitas Atma Jaya Yogyakarta \\ Jl. Babarsari 44, Yogyakarta, Indonesia. 55281 \\ Email: brsidharta@gmail.com/brsidharta@uajy.ac.id \\ ${ }^{3}$ Faculty of Pharmacy, Universitas Sanata Dharma \\ Jl. Paingan, Maguwoharjo, Sleman, Yogyakarta, Indonesia. 55284 \\ Email: yustinahartini@usd.ac.id
}

Received 10 September 2018; Received in revised form 30 March 2019;

Accepted 19 June 2019; Available online 30 June 2019

\begin{abstract}
Red ginger (Zingiber officinale var. rubrum) has been proven to show anticancer activity. Direct use bioactive compound from red ginger has many obstacles such as large amount of red ginger's rhizome needed, limitation of planting area, and very long time of harvesting. Utilization of endophytic fungi from red ginger's rhizome could be an alternative to the problems. The aims of this study were to determine bioactive compound produced by endophytic fungi and toxicity activity based on $\mathrm{LC}_{50}$. Endophytic fungi were isolated from red ginger and were identified macroscopically and microscopically. The bioactive compounds were extracted using ethanol $96 \%$. Flavonoid test was done qualitatively, bioactive compounds were analyzed by Thin Layer Chromatography (TLC), and the toxicity test was done using Brine Shrimp Lethality Assay (BSLA). The present research found two endophytic fungi isolated from red ginger rhizome. Isolate 1 was similar to Mucor sp. and isolate 2 was similar to Trichoderma sp. Phytochemical test revealed bioactive compound extracted from the isolates were contained flavonoid. TLC analysis did not detect quercetin from the bioactive compound extracted from the isolates. $\mathrm{LC}_{50}$ values of the bioactive compound from the isolates were 2.300 and $1.747 \mu \mathrm{g} / \mathrm{ml}$, respectively. The toxicological results suggest that both isolates produce non-toxic compound to Artemia salina.
\end{abstract}

Keywords: brine shrimp lethality assay; endophytic fungi; red ginger; toxicity

\section{INTRODUCTION}

Red ginger (Zingiber officinale var. rubrum) contains bioactive compounds that have capabilities as anticancer, such as flavonoid, gingerol, and shogaol (Danciu et al., 2015; Semwal et al., 2015). Usage of the bioactive compounds directly from ginger faces many obstacles, i.e. large biomass needed, land use limitation, and length of harvesting time (Ginting, 2013). One of the alternatives to solve the problems is to utilize endophytic fungi from red ginger.

Endophytic fungi are a group of microorganism that all or parts of their lives are found in the plant tissues (Kumara et al., 2014). Endophytic fungi produce useful bioactive substances such as antimicrobial, fungicide, antivirus, and antioxidant (Lakshmi \& Selvi,
2013). Usage of endophytic fungi as sources of bioactive substances is believed to give benefits, i.e. substances produced are homogenous, fast production, ease to be scaled up, and the amount of productions can be multiplied (Kumara et al., 2012).

Brine Shrimp Lethality Assay (BSLA) is the initial screening method for anticancer substances (Kolbeck \& Tintjer, 2016). BSLA is done based on acute toxicity of an extract to Artemia salina larvae by LC50 value after 24 hours treatment. If LC50 $<1000 \mu \mathrm{g} / \mathrm{ml}$, the sample extract is considered to have high toxic effect and is hoped to have cytotoxic effect that becomes a prerequisite for an anticancer substance (Kolbeck \& Tintjer, 2016; Bücker et al., 2013). 
Kaitu et al. (2013) reported that endophytic fungi found from red ginger rhizome was able to inhibit Escherichia coli and Streptococcus pyogenes. Endophytic fungi isolated from red ginger rhizome were also able to inhibit pathogenic fungi Fusarium oxysporum (Ginting, 2013). However, the bioactive substances produced by the endophytic fungi and their toxicity have never been reported.

The objectives of the research are to determine bioactive substances produced by endophyte fungi isolated from red ginger qualitatively, toxicity level of the bioactive substances utilizing BSLA method, and $\mathrm{LC}_{50}$ value of the bioactive substances.

\section{MATERIALS AND METHODS}

Red ginger rhizomes were purchased from cultivation field at Rajek Lor village, Mlati subdistrict, Sleman district, Yogyakarta Special Province. Other materials used were as follows eggs of Artemia salina from Balai Besar Pengembangan Budidaya Air Jepara, Central of Java.

PDA and PDB media preparations. PDA medium was made by diluting $39 \mathrm{~g}$ PDA powder in $1 \mathrm{~L}$ aquadest and adding it with chloramphenicol antibiotic $0.5 \mathrm{~g} / \mathrm{L}$, stirred and boiled to dilute. Afterward it was sterilized in the autoclave for $15 \mathrm{~min}$ at $121^{\circ} \mathrm{C}$ and $1.5 \mathrm{~atm}$ (Sigma Aldrich, 2017). PDB medium was made by slicing $300 \mathrm{~g}$ potato, then add with $1000 \mathrm{ml}$ aquadest. The medium was boiled and then filtered. As much as $500 \mathrm{ml}$ of the potato extract was put into a bottle and add with $10 \mathrm{~g}$ dextrose and $\mathrm{NH}_{4} \mathrm{NO}_{3} 1 \%$. The media were sterilized with autoclave at $121^{\circ} \mathrm{C}$ for $15 \mathrm{~min}$ (Sigma Aldrich, 2017).

Pure culture of endophyte fungi. Red ginger rhizomes were cleansed with running water. The rhizomes were sterilized by soaking into ethanol $70 \%$ for 1 minute and then were rinsed three times with sterile water. The rhizomes were soaked again into hypochlorite solution $0.5 \%$ for $5 \mathrm{~min}$ and were rinsed for six times with sterile water. Red ginger rhizomes were cut into smaller sizes, i.e. $2 \times 2 \times 2 \mathrm{~cm}^{3}$. The pieces of rhizome were put on the surface of PDA medium and were incubated at $28^{\circ} \mathrm{C}$. Observations were done everyday to determine the growth of endophytic fungi after isolation (Ginting, 2013; Sadrati et al., 2013). Colonies of endophytic fungi growth were purified in new PDA medium and incubated for 5 days. If there were different colonies growth at the PDA medium, thus it will be re-isolated until pure culture was obtained. The pure culture of endophytic fungi was grown on agar slant to be identified (Noverita et al., 2009).

\section{Endophytic fungi identification.} Identification was done macroscopically by observing the morphology, textures, and colors of the colonies. Microscopic identification was done by observing the types of mycelia, spores, and conidia. Microscopic identification was done using lactophenol cotton blue dyes. The identification was done based on Rodriguez et al., (2009); Ginting et al. (2013).

Cultivation and production of secondary metabolites. Endophytic fungi were rejuvenated in PDA slant media and were incubated at $28^{\circ} \mathrm{C}$ for 5 days. Cultivation of the endophytic fungi were done by transferring the isolates into $100 \mathrm{ml}$ PDB media. PDB medium was incubated for 7 days at $30^{\circ} \mathrm{C}$ into shaker incubator at $120 \mathrm{rpm}$ (Sadrati et al., 2013; Lakshmi \& Selvi, 2013; Li et al., 2015). Fermentation medium was separated from the mycelia by filtration and was rinsed with ethanol 96\%. Extraction process was done by adding ethanol $96 \%$ into the fermentation medium (1:1). The solvent which contains bioactive substances was evaporated using rotary evaporator and put into the oven to get the viscous extract (Nath et al., 2012).

Qualitative flavonoid test. The test was done by adding $5 \mathrm{ml}$ ethanol to $50 \mathrm{mg}$ extract and was boiled for 5 minutes. The solution was added with 5 drops of concentrated $\mathrm{HCl}$ and 1 mg powder. Positive results which determine the existence of flavonoid were shown by the appearance of yellow, pink or purple colors (Ali et al., 2018; Sangi et al., 2008).

Bioactive substance analysis. Bioactive substance extracts were weighed as much as 5 $\mathrm{mg}$, diluted into $5 \mathrm{ml}$ methanol, and filtered. Quercetin as the standard substance was weighed as much as 0.01 gram, diluted into 10 $\mathrm{ml}$ methanol. Silica gel plate $60 \mathrm{GF}_{254}$ sizes 9 $\mathrm{cm}$ x $5 \mathrm{~cm}$ was used. Sample substance and 
quercetin were spotted at the distance of $1.5 \mathrm{~cm}$ from the lower part of the silica plate. The plate was put into the jar that contains mobile phase composed of toluene:ethyl acetate:methanol $(5: 3: 2)$. The plate was put at the borderline and was observed by UV lamp at the wavelength $254 \mathrm{~nm}$, and the $\mathrm{R}_{\mathrm{f}}$ values were then measured (Males et al., 2013; Preethi et al., 2017; Rao \& Ahmed, 2013).

Hatching of Artemia. Two g of Artemia eggs were hatched in the aquarium filled with $500 \mathrm{ml}$ seawater and equipped with aerator. Seawater temperatures were set at $25-30^{\circ} \mathrm{C}$ and supported with LED lamps. After 48 hours, Artemia eggs will be hatched into larvae, the latter were pipetted and ready to be used in the toxicity test (Kolbeck \& Tintjer, 2016; Eimanifar, 2014).

Preliminary toxicity test. Preliminary toxicity test was done to determine the critical concentration ranges to be applied at the determinative toxicity test (Bücker et al., 2013). At the preliminary test, every ten larvae of $A$. salina were put into small bottle with extract solutions at different concentrations, namely 0 , $10,100,1000 \mu \mathrm{g} / \mathrm{ml}$. The toxicity tests were done in five replications. After 24 hours, the percentage of death larvae was counted (Naidu et al., 2014; Hiola \& Bahri, 2010).

Determinative toxicity test. BSLA was done by putting every ten $A$. salina larvae aged 48 hours into bottle filled with $5 \mathrm{ml}$ extract solution with the concentration determined from preliminary test and was added with $5 \mathrm{ml}$ seawater. The control treatment was seawater with ten A. salina larvae without extract. The bottles were incubated for 24 hours with LED lamps. After 24 hours, the numbers of life larvae were counted (Kolbeck \& Tintjer, 2016; Naidu et al., 2014). The criterion of life larvae was larvae that still able to move for few seconds during observations (Rajabi et al., 2015).

Data Analysis. Data were analyzed using probit to determine $\mathrm{LC}_{50}$ value. Extracts were considered as toxic if the $\mathrm{LC}_{50}$ values are lower than $1000 \mu \mathrm{g} / \mathrm{ml}$ (Kolbeck \& Tintjer, 2016).

\section{RESULT AND DISCUSSION}

Isolation of Endophytic Fungi. There were two isolates of endophytic fungi isolated from red ginger rhizome (Figure 1).
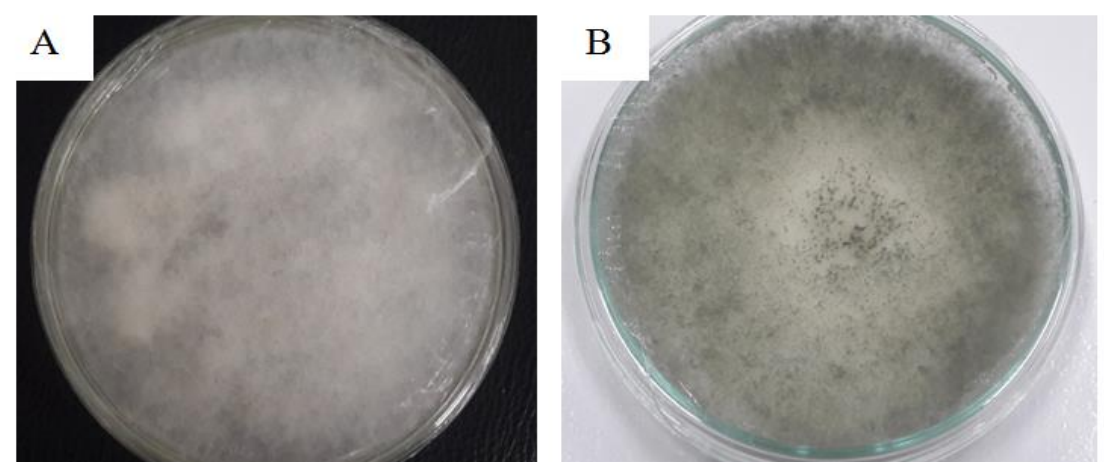

Figure 1. Pure culture of endophytic fungi isolated from red ginger rhizome: A. Isolate 1 with white coloration as cotton; B. Isolate 2 with black green colour

Macroscopic characteristics of the isolate 1 were white color, smooth as cotton, and colony's back color was yellowish white; while the microscopic characters observed were the types of sporangiophore, sporangium, columella, and sporangiospore (Figure 2). Macroscopic and microscopic characteristics showed that isolate 1 was very similar to Mucor sp. and according to Rodriguez et al. (2009) the species that has white colony color and can be changed into greyish brown was identified as Mucor racemosus, while colony with back color yellowish white was identified as Mucor hiemalis, and species with thick walled and branched sporangiospores was identified as Mucor plumbeus. The isolate 1 was also similar to Rhizopus sp., but differ in that Rhizopus sp. has rhizoid, while Mucor sp. does not have rhizoid (Purwantisari \& Hastuti, 2009; Rodriguez et al., 2009). 


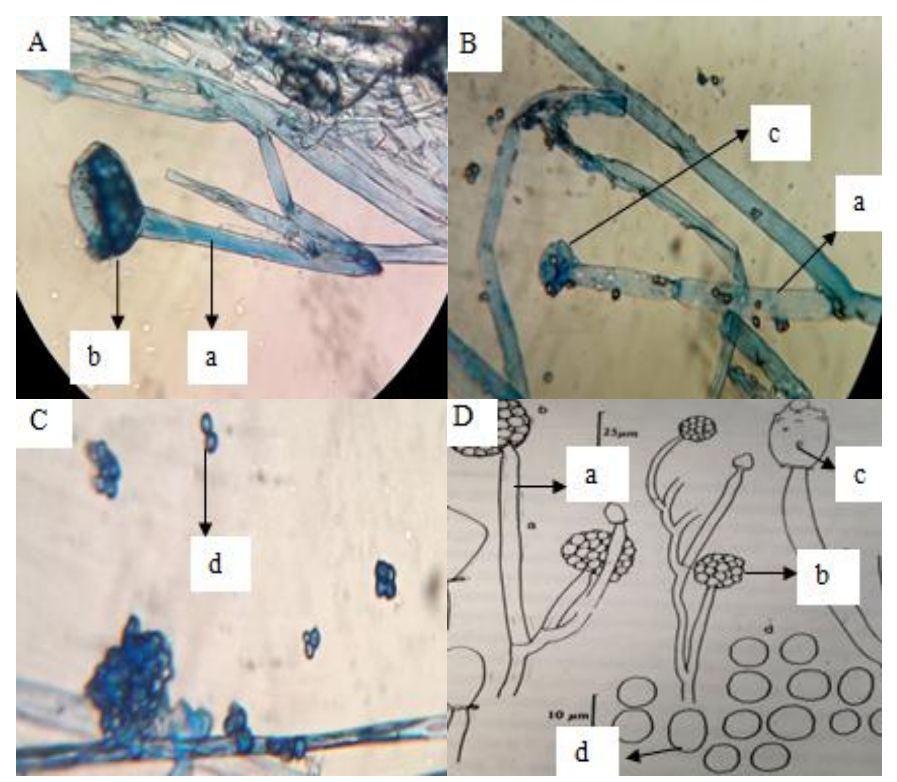

Figure 2. A-C. Morphology of isolate 1 by lactophenol cotton blue dyes and observed under light microscope at $450 \mathrm{x}$; D. Morphology of one of the species of Mucor sp., i.e. Mucor plumbeus (Purwantisari \& Hastuti, 2009); a. Sporangiophore; b. Sporangium; c. columella; d. round shape sporangiospore

Macroscopic characteristics of isolate 2 (Figure 1B) were black green in color, rough surface, and colony's back color were white, while its microscopic characteristics (Figure 3) showed the existence of conidiophore, round shape conidium, and phyalides or cells that formed conidium. The characters were very similar to Trichoderma sp. Rodriguez et al., (2009) stated that Trichoderma sp. colony has no color at the beginning but will change to greenish white and turned into dull green; has no color for the colony's back. Change of colony color was due to the age of the colony.
Colony of young Trichoderma will have white color, but later it will turn into green and finally into black green (Suparno et al., 2016). Macroscopically it has the same color as Penicillium sp., i.e. from greyish green (Penicillium griseofulvum) to dark green (Penicillium purpurogenum). The difference was seen microscopically i.e. Penicillium sp. has metulae that is the apical branch of conidiophore that bring phyalides, while at Trichoderma sp. metulae does not exist at all (Rodriguez et al., 2009).

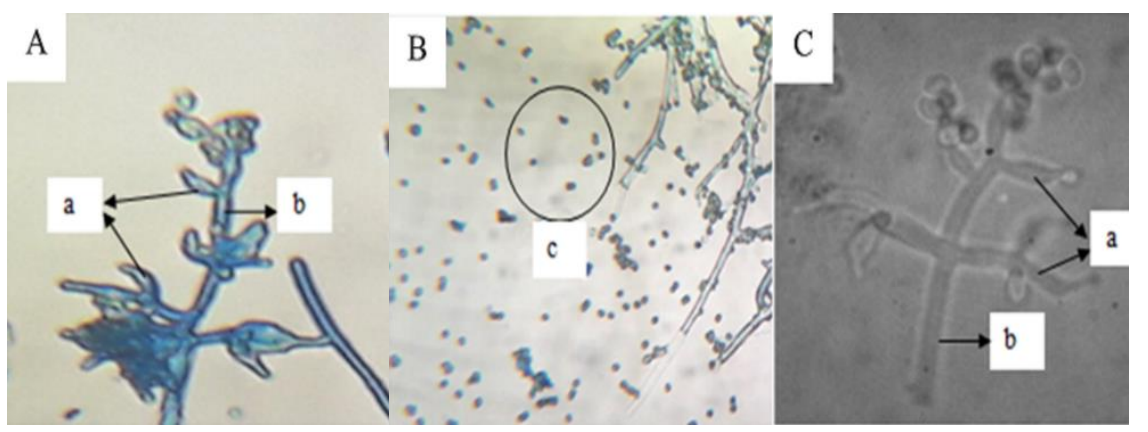

Figure 3. A. Morphology of isolate 2 with lactophenol cotton blue dyes observed under light microscope at $450 \mathrm{x}$; B. Morphology of conidia from isolate 2 with lactophenol cotton blue dyes at $450 \mathrm{x}$; C. Morphology of Trichoderma sp. at 1000 x (Purwantisari \& Hastuti, 2009); a. fialid or cells that formed conidia; b. conidiophore; c. semicircle conidia shape

Kaitu et al. (2013) found an isolate that was similar to Mucor sp. from red ginger rhizome. Ginting (2013) isolated Mucor sp. and Trichoderma sp., but was not from red ginger rhizome. The existence of endophytic fungi in plant tissues were influenced by climate and geographical position as well as culture medium used; since culture medium gave 
similar conditions to natural habitat of endophytic fungi. The mechanism adaptation of endophytic fungi to physiological and microecological conditions of the plant's hosts were well noted (Costa et al., 2012; Fernandes et al., 2015; Noverita et al., 2009).

Qualitative Flavonoid Test. The result of flavonoid qualitative test showed that both isolates were able to produce flavonoid (Table 1). Yellow color appeared due to reduction reactions between $\mathrm{Mg}, \mathrm{HCl}$, and the samples (Danciu et al., 2015). Endophytic fungi were able to produce flavonoid through shikimate pathway that is started with condensation process between phosphoenolpyruvate (PEP) and erythrose-4-phosphate (E-4-P) (Tohge et al., 2013). Shikimate pathway produces chorismate that will become the precursor for phenylalanine and the latter will become the precursor for flavonoid (Tohge et al, 2013).

Table 1. Flavonoid qualitative test

\begin{tabular}{cccc}
\hline Isolate & Initial Colour & End Colour & Test Result \\
\hline Isolate 1 & White & Yellow & + \\
\hline Isolate 2 & White & Yellow & + \\
\hline$+=$ contain flavonoid & & &
\end{tabular}

Biosynthesis of flavonoid was also done through malonic acid pathway that produced malonyl CoA. Three molecules of malonyl CoA will undergo condensation with one molecule of 4-co

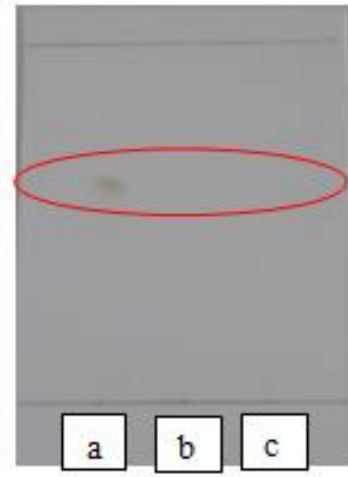

A

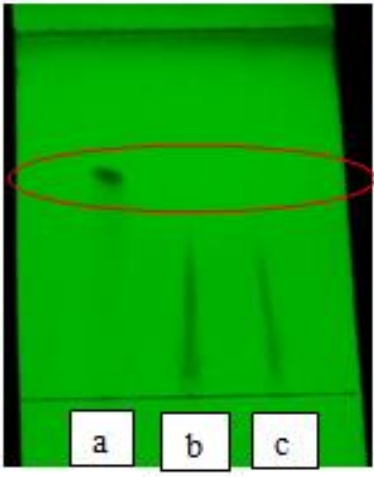

B chalcone synthase to produce chalcone. Chalcone was isomerized into naringenin that will undergo several reactions to produce flavanone, flavonol, flavanol, and anthocyanin

Figure 4. TLC results: A. without UV light; B. UV light with wavelength $254 \mathrm{~nm}$; C. UV light with wavelength $365 \mathrm{~nm}$. a. Standard quercetin with $\mathrm{R}_{\mathrm{f}}$ value of 0.67 ; $\mathrm{b}$. Extract of isolate 1 ; c. Extract of isolate 2

TLC analysis showed $R_{f}$ value for quercetin standard at 0.67 (Figure 4). Extracts from isolate 1 and 2 were not able to show clear spots at $R_{f}$ value 0.67 . Extracts of bioactive substance from isolate 1 and 2 did not produce quercetin, which was one of the members of flavonoid. Quercetin was not detected from the extracts of both isolates due to very low concentrations. Preethi et al., (2017) reported that one of the disadvantages of TLC i.e. it cannot detect low concentration of substances. Other possibility was that the endophytic fungi did not produce quercetin due to ecological factors such as rain falls, climate, and nutrient contents in the soil affected secondary metabolites production (Liu et al., 2015).

Figure 4 showed sample substances that were not fully separated by the mobile phase used. Imperfect separation was due to interaction of substances involved, for instance polar substance can form hydrogen bonds; substances bind to immobile phase, and mobile phase did not work optimally. Thus, advance elution needs to be done to utilize mobile phase with different polarity levels (Santosa \& Haresmita, 2015).

Toxicity Test. Preliminary toxicity test was done and the result of the death percentage of A. salina larvae at concentration $1000 \mu \mathrm{g} / \mathrm{ml}$ 
was as high as $30 \%$. The concentration was then needed to be increased in order to reach higher percentage value. For determinative toxicity test the concentrations used were varied, namely 1000, 2000, 3000, 4000, and 5000 $\mu \mathrm{g} / \mathrm{ml}$ (Table 2).

Table 2. Toxicity of bioactive substances from isolate 1 and isolate 2

\begin{tabular}{cccccccc}
\hline \multirow{2}{*}{ Isolate } & \multicolumn{5}{c}{ Average Death of $\boldsymbol{A}$. salina larvae (\%) } \\
\cline { 2 - 7 } & \multicolumn{4}{c}{ Concentration $(\mu \mathrm{g} / \mathrm{ml})$} & \multirow{2}{*}{ Control } \\
\cline { 2 - 7 } & 2800 & 2000 & 3000 & 4000 & 5000 & \\
\hline Isolate 1 & 38 & 52 & 60 & 70 & 78 & 2 \\
\hline Isolate 2 & & & & & \\
\hline
\end{tabular}

$\mathrm{LC}_{50}$ of the bioactive compound from the isolates were 2,300 and $1,747 \mu \mathrm{g} / \mathrm{ml}$, respectively. Bioactive substances from isolate 1 and 2 yielded $\mathrm{LC}_{50}$ value $>1000 \mu \mathrm{g} / \mathrm{ml}$ and categorized as not toxic (Kolbeck \& Tintjer, 2016). LC $_{50}$ value less than 1000 ppm means that the bioactive substance tested has the potential effect as anticancer, but if the value is higher than 1000 ppm means the bioactive substance has no potency as anticancer (Pasilala et al., 2016). Therefore, bioactive substances from isolate 1 and 2 did not show any potency as anticancer.

Flavonoid can kill A. salina larvae by disrupting larvae cell walls, inhibiting enzyme activities, disturbing the function of larvae cell membrane, and inhibiting protein synthesis due to the activation of $\alpha$-subunit of eukaryotic initiation factor 2 (eIF2 $\alpha)$. Thus phosphorylation was occurred at eIF $2 \alpha$ kinase that caused failure of initiation of mRNA translation (Ginting et al., 2013; Roy, 2016). Death of $A$. salina larvae could also cause by flavonoid that gave up its $\mathrm{OH}^{-}$group to bind to cell membrane integral protein of A. salina larvae. The $\mathrm{OH}^{-}$group that binds to cell membrane integral protein will inhibit active transport of $\mathrm{Na}^{+}$and $\mathrm{K}^{+}$, thus influx of $\mathrm{Na}^{+}$to the cells becomes uncontrolled and caused the cell membrane rupture (Chen et al., 2014).

\section{CONCLUSION}

The present research concluded that Isolate 1 and 2 produce bioactive substances such as flavonoid, but quercetin was not detected in the extracts from the two isolates, not toxic based on BSLA, with $\mathrm{LC}_{50}$ value at $2.300 \mu \mathrm{g} / \mathrm{ml}$ (isolate 1), while isolate 2 at $1.747 \mu \mathrm{g} / \mathrm{ml}$.

\section{ACKNOWLEDGMENTS}

The researchers are indebted to Faculty of Biotechnology Universitas Atma Jaya Yogyakarta for permitting the research using laboratory facilities. Thank you to Research and Community Service Center Universitas Atma Jaya Yogyakarta for partially funding the research.

\section{REFERENCES}

Ali AMA, El-Nour MEM, Yagi SM. 2018. Total phenolic and flavonoid contents and antioxidant activity of ginger (Zingiber officinale Rosc.) rhizome, callus and callus treated with some elicitors. Journal of Genetic Engineering and Biotechnology. vol 16(2): 677-682. doi: https://doi.org/10.1016/j.jgeb.2018.03.003

Bücker A, Falcão-Bücker NC, Nunez CV, Pinheiro CCS, Tadei WP. 2013. Evaluation of larvicidal activity and brine shrimp toxicity of rhizome extracts of Zingiber zerumbet (L.) Smith. Revista da Sociedade Brasileira de Medicina Tropical. vol 46(3): 377-380. doi: http://dx.doi.org/10.1590/0037-86821309-2013.

Costa IPMW, Maia LC, Cavalcanti MA. 2012. Diversity of leaf endophytic fungi in mangrove plants of northeast Brazil. Brazilian Journal of Microbiology. vol 43(3): 1165-1173. doi: 10.1590/S1517838220120003000044.

Danciu C, Vlaia L, Fetea F, Hancianu M, Coricovac DE, Ciurlea SA, Şoica CM, Marincu I, Vlaia V, Dehelean CA, Trandafirescu C. 2015. Evaluation of phenolic profile, antioxidant and 
anticancer potential of two main representants of Zingiberaceae family against B164A5 murine melanoma cells. Biological Research. vol 48(1): 1-9. doi: 10.1186/0717-6287-48-1.

Eimanifar A. 2014. Molecular phylogeography and population genetics of the brine shrimp Artemia (Crustacea, Branchiopoda, Anostraca). [Dissertation]. Heidelberg: Faculty of Natural Sciences and Mathematics, University of Heidelberg, Germany

Fernandes EG, Pereira OL, da Silva CC, Bento CBP, de Queiroz MV. 2015. Diversity of endophytic fungi in Glycine max. Microbiological Research. vol 181: 84-92. http://dx.doi.org/10.1016/j.micres.2015.05 .010 .

Ginting RCB. 2013. Keragaman cendawan endofit yang diisolasi dari berbagai spesies tanaman obat potensial. [Tesis]. Bogor: Program Studi Mikrobiologi IPB.

Ginting RCB, Sukarno N, Widyastuti U, Darusman LK, Kanaya S. 2013. Diversity of endophytic fungi from red ginger (Zingiber officinale Rosc.) plant and their inhibitory effect to Fusarium oxysporum plant pathogenic fungi. HAYATI Journal of Biosciences. vol 20(3): 127-137. doi: 10.4308/hjb.20.3.127.

Hiola SF, and Bahri A. 2010. Uji toksisitas ekstrak daun ketepeng cina (Cassia alata L.) pada keong mas (Pomacea canaliculata L.). Bionature. vol 11(2): 115-119.

Kaitu RAM, Sidharta BR, Atmodjo K. 2013. Aktivitas Antibakteri Fungi Endofit Jahe Merah (Zingiber officinale var. rubrum) Terhadap Escherichia coli dan Streptococcus pyogenes. Jurnal Biologi. p 1-15.

Kolbeck MK, and Tintjer TE. 2016. The use of a brine shrimp assay to detect bioactivity in the endophyte infected grass, Agrostis hyemalis. Journal of the Pennsylvania Academy of Science. vol 90(1): 13-20.

Kumara PM, Zuehlke S, Priti V, Ramesha BT, Shweta S, Ravikanth G, Vasudeva R, Santhoshkumar TR, Spiteller M, Shaanker RU. 2012. Fusarium proliferatum, an endophytic fungus from Dysoxylum binectariferum Hook.f, produces rohitukine, a chromane alkaloid possessing anti-cancer activity. Antonie van Leeuwenhoek. vol 101: 323-329. doi: 10.1007/s10482-011-9638-2.

Kumara PM, Shweta S, Vasanthakumari MM, Sachin N, Manjunatha BL, Jadhav SS, Ravikanth G, Ganeshaiah KN, Shaanker RU. 2014. Endophytes and plant secondary metabolite synthesis: molecular and evolutionary perspective. In: V.C. Verma and A.C. Gange (eds.). Advances in Endophytic Research. doi: 10.1007/97881-322-1575-2_9.

Lakshmi PJ, and Selvi KV. 2013. Anticancer potentials of secondary metabolites from endophytes of Barringtonia acutangula and its molecular characterization. International Journal of Current Microbiology and Applied Sciences. vol 2(2): 44-45.

Li X, Guo Z, Deng Z, Yang J, Zou K. 2015. A new a-pyrone derivative from endophytic fungus Pestalotiopsis microspora. Rec. Nat. Prod. vol 9(4): 503-508.

Liu W, Liu J, Yin D, Zhao X. 2015. Influence of ecological factors on the production of active substances in the anticancer plant Sinopodophyllum hexandrum (Royle). PloS One. vol 10(4): 1-22. https://doi.org/10.1371/journal.pone.0122 981.

Males C, Saric D, Bojic M. 2013. Quantitative determination of flavonoids and chlorogenic acid in the leaves of Arbutus unedo L. using thin layer chromatography. Journal of Analytical Methods in Chemistry. vol 2013: 1-4. doi: http://dx.doi.org/10.1155/2013/385473.

Naidu JR, Ismail R, Sasidharan S. 2014. Acute Oral Toxicity and Brine Shrimp Lethality of Methanol Extract of Mentha spicata L (Lamiaceae). Tropical Journal of Pharmaceutical Research. vol 13(1): 101107. doi: http://dx.doi.org/10.4314/tjpr.v13i1.15.

Nath A, Raghunatha P, Joshi SR. 2012. Diversity and biological activities of endophytic fungi of Emblica officinalis, an 
ethnomedicinal plant of India. Mycobiology. vol 40(1): 8-13. doi: 10.5941/MYCO.2012.40.1.008.

Noverita, Fitria D, Sinaga E. 2009. Isolasi dan uji aktivitas antibakteri jamur endofit dari daun dan rimpang Zingiber ottensii Val. Jurnal Farmasi Indonesia. vol 4(4): 171176.

Pasilala FB, Daniel, Saleh C. 2016. Uji toksisitas (Brine Shrimp Lethality Test) dan aktivitas antioksidan dari daun sintrong (Crassocephalum crepidioides) dengan metode 2,2-diphenyl-1-picrylhidrazil (DPPH). Jurnal Kimia Mulawarman. vol 14(1): 13-18.

Preethi J, Harita B, Rajesh T. 2017. Review on Thin Layer Chromatography. Journal of Formulation Science and Bioavailability. vol 1(2017): 107.

Purwantisari S, and Hastuti RB. 2009. Isolasi dan identifikasi jamur indigenous rhizosfer tanaman kentang dari lahan pertanian kentang organik di Desa Pakis, Magelang. Bioma. vol 11(2): 45-53. doi: https://doi.org/10.14710/bioma.11.2.4553.

Rajabi S, Ramazani A, Hamidi M, Naji T. 2015. Artemia salina as a model organism in toxicity assessment of nanoparticles. DARU Journal of Pharmaceutical Sciences. vol 23(1): 20. doi: 10.1186/s40199-015-0105-x.

Rao AS, and Ahmed MF. 2013. Simultaneous estimation of quercetin and rutin in ethanolic extract of Melia azedarach. Linn leaves by HPTLC method. Asian Journal of Biomedical and Pharmaceutical Sciences. vol 3(21): 56-69.

Rodriguez RJ, White Jr JR, Arnold AE, Redman RS. 2009. Fungal endophytes: diversity and functional roles. New Phytologist. vol 182: 314-330. doi: 10.1111/j.1469-8137.2009.02773.x.

Roy S. 2016. Polyphenol Content and Differential Expression of Flavonoid Biosynthetic Pathway Genes of Fragaria spp with white fruit. [Dissertations].
Lexington: Department of Plant and Soil Sciences. doi: http://dx.doi.org/10.13023/ETD.2016.033. Sadrati N, Daoud H, Zerroug A, Dahamna S, Bouharati S. 2013. Screening of antimicrobial and antioxidant secondary metabolites from endophytic fungi isolated from wheat (Triticum durum). Journal of Plant Protection Research. vol 53(2): 128136.

Sangi M, Runtuwene MRJ, Simbala HEI, Makang VMA. 2008. Analisis fitokimia tumbuhan obat di kabupaten Minahasa Utara. Chem. Prog. vol 1(1): 47-53.

Santosa D, and Haresmita PP. 2015. Antioxidant activity determination Garcinia dulcis (Roxb.) Kurz, Blumeamollis (D. Don) Merr, Siegesbeckia orientalis L. and Salvia riparia H. B. K. which collected from Taman Nasional Gunung Merapi using DPPH (2,2diphenyl-1-pikril-hidrazil) and thin layer chromatography. Traditional Medicine Journal. vol 20(1): 28-36. doi: https://doi.org/10.22146/tradmedj.7746.

Semwal RB, Semwal DK, Combrinck S, Viljoen AM. 2015. Gingerols and shogaols: important nutraceutical principles from ginger. Phytochemistry. vol 117: 554-568. doi: 10.1016/j.phytochem.2015.07.012.

Sigma Aldrich. 2017. Fungal and bacterial detection media. http://www.sigmaaldrich.com.

Suparno, Sukoso, Hakim L, Aidawati N. 2016. Trichoderma spp. as agent of biological control in local rice diseases in tidal swamp lands in South Kalimantan, Indonesia. Journal of Agriculture and Veterinary Sciences. vol 9(1): 1-6. doi: 10.9790/238009120106.

Tohge T, Watanabe M, Hoefgen R, Fernie AR. 2013. Shikimate and phenylalanine biosynthesis in the green lineage. Frontiers in Plant Science. vol 4(62): 1-13. doi: 10.3389/fpls.2013.00062 